\title{
Innovation as a driver of eco-innovation in the firm: an approach from the dynamic capabilities theory
}

\begin{abstract}
The aim of this study is to investigate how innovative capabilities of the firm affect ecoinnovation from a dynamic capability lens. We build on OECD's (2005) research to conceptualise eco-innovation as the capacity with which firms modify, re-design, and create products, processes, procedures and organisations in order to reduce environmental impact. We propose and test the temporal and relational properties of eco-innovation as a capability. We demonstrate that eco-innovation possesses two properties of innovative capabilities, namely, persistence over time and interrelation with other innovations. We thus shed new light on the mechanism through which firms engage in eco-innovation. We also provide empirical evidence to the debate on the relationship between the 'normal' innovation (technological or nontechnological) and eco-innovation. We show that eco-innovation and innovation are interrelated both simultaneously and sequentially. Moreover, we show that innovation capabilities and eco-innovation are not only related, but they also have a complementary nature, which facilitates the development of future eco-innovation.
\end{abstract}

Keywords: Eco-innovation, dynamic capabilities, persistence over time, interrelation.

\section{Introduction}

Over recent years, eco-innovation (EI) has become an important driver of economic development (Ambec et al., 2013; Borghesi et al., 2015; Arena et al., 2017). Eco-innovation is recognised as an important means to achieve sustainable development in the society, and as such the growing demand for environmental protection at both global and local levels have resulted in an increase in the supply of environment-friendly techniques, products and services. Moore et al. (2014) and Tatoglu et al. (2019) highlight the important role firms play in the development of eco-innovations. The European Union (Eco-Innovation Observatory, 2018) points out that this sector now made up around 2.2\% of GDP in the European Union. Moreover, eco-innovation and sustainable development are considered crucial drivers of the competitiveness of companies. In fact, firms could undertake eco-innovation to foster and sustain business competitiveness by doing something smarter than their rivals in addressing environmental impacts while simultaneously improving the affected product itself and/or related processes as well as by reaping first-mover advantage with their low-pollution and energy-efficient products in international markets (Porter \& Van der Linde, 1995). 
Recent literature has investigated the explanatory variables for eco-innovation drivers (Zubeltzu-Jaka et al., 2018; Constantini et al., 2017; Dangelico et al., 2017; Novellie et al., 2016; Del Río et al., 2015; Triguero et al., 2013; Horbach et al, 2012). Demirel and Kesidou (2019) recognize that there is a consensus in this literature regarding regulation, technology push, and market pull as drivers of eco-innovation, while in contrast there is a lack of agreement on the role firms' capabilities play in fostering eco-innovation. Therefore, Hofman et al., (2012) point out that exploration of which capabilities are antecedents of the implementation of eco-innovation is a fundamental question for understanding eco-innovation, and Demirel and Kesidou (2019) also highlight the dearth of empirical evidence in this topic.

In response to the research gap, our paper explores how firms' innovative capabilities affect eco-innovation. Previous literature has somehow addressed this question with yet colliding arguments and inconclusive findings (Demirel and Kesidou, 2019; Bossle et al., 2016; Cai and Zhou, 2014; Hofman et al., 2012; Cainelli et al., 2012). On the one hand, one stream of studies considers innovation itself to be a facilitator of eco-innovation development (Chassagnon and Haned, 2015; Ambec et al., 2013; Horbach et al., 2012; Hofman et al., 2012; CarrilloHermosilla et al., 2010). These studies are based on the view that innovation is a cumulative process of skills and capability building that in turn spurs subsequent eco-innovation, highlighting innovation as a step prior to eco-innovation (Chassagnon and Haned, 2015). On the other hand, another stream of studies argues that eco-innovation and regular innovation follow different paths (Demirel and Kesidou, 2019; Cuerva et al., 2014; Foulon et al., 2002). Demirel and Kesidou (2019) thus suggest that firms should develop sustainability-orientated capacities, in order to meet the rapidly changing regulatory, technology, and market demands. Overall, both streams of studies have focused on differentiating between innovation and ecoinnovation.

In this paper, we use the dynamic capabilities theory as a theoretical lens, and build on the OECD's definition of eco-innovation (OECD, 2005) to conceptualize eco-innovation as the mechanism for implementing certain environmental and sustainable products and services at the firm level. More specifically, we conceptualise eco-innovation as a capability, similar to innovation capability (Cohen and Levinthal, 1990). The implications of such a conceptualisation are twofold. First, eco-innovation should interact with other innovation capabilities. Previous literature has pointed out that there is an interrelation among different types of innovation as a consequence of the execution of routines and processes, with the potential of producing synergies in the learning (complementarity). Thus, we analyse the interactions between technological and non-technological innovations and eco-innovation, 
exploring the following question: how do technological and non-technological innovations interact with eco-innovation? Second, prior innovation should facilitate subsequent innovation. While previous literature on innovation capabilities has confirmed the existence of the persistence in the time property (i.e. previous innovation fosters future innovation activities) in technological and non-technological innovations, this issue has received very little attention in the eco-innovation literature at the firm level (with the exception of Horbach, 2008). We thus explore the following question: does past eco-innovation increase the probability of being ecoinnovative in the future?

\section{Conceptual Framework}

\section{Dynamic Capabilities Theory}

Our paper is framed in the dynamic capabilities theory (Zahra et al., 2006, Teece, 2007, Nelson and Winter, 2002, Eisenhardt and Martin, 2000). Teece et al. (1997) put forward the dynamic capabilities perspective as an extension of the resource-based view of the firm (Barney et al., 2001). Teece et al. (1997: 516) considered the dynamic capabilities as "the firm's ability to integrate, build, and reconfigure internal and external competencies to address rapidly changing environments". Eisenhardt and Martin (2000) have presented dynamic capabilities as specific and identifiable processes, while Nelson and Winter (2002) considered the dynamic capabilities as foreseeable behavioural patterns, through which the organisation manages its resource, with the objective of obtaining the success of the company. Additionally, Teece (2007) points out those firms' capabilities enable them to develop innovation. Therefore, dynamic capabilities encompass the management of capabilities and resources of all functions of firms, with the final objective to get a competitive advantage.

\section{Eco-innovation as innovation capability of the firm}

There are several definitions of the term eco-innovation, as presented in Table 1. In general, eco-innovation refers to innovation in new products, services or new business practices, necessary to create new business opportunities and benefits to the environment. Horbach et al. (2012) and Ambec et al. (2013) conclude that eco-innovation can be defined as a type of innovation, which provides environmental benefits.

OECD (2005) emphasizes eco-innovation as the capacity to modify, re-design, and create products, processes, procedures and organisations in order to reduce environmental impact. Built on this idea, in this paper, we conceptualize eco-innovation as an innovation capability. This is in line with Cohen and Levinthal's (1990) conceptualization, of innovation capability as a series of processes and organisational routines that allow the company to seek out, acquire, 
assimilate and use resources to improve the firm's performance. Innovation capabilities manifest themselves in firms' innovation processes; that is, the capabilities of organisations to successfully adopt and implement new ideas, processes and products. Hence, this paper argues that eco-innovation should possess two characteristics of innovative capability ${ }^{1}$, namely persistence over time and interrelation with other innovation capabilities.

\section{Hypotheses}

\section{Persistence over time of eco-innovation}

Framing eco-innovation as an innovation capability implies that the development of previous eco-innovations affects the development of future eco-innovation. This is consistent with recent studies on the persistence of technological innovations (Peters, 2009; Sapprasert and Clausen, 2012; Tavassoli and Karlsson, 2015), which consider the innovation process as a process of "creative accumulation", whereby knowledge obtained from past innovation fosters new innovations, as a consequence of learning and the generation of economies of scale during the development process. For example, Spokas et al. (2012) point out that the development of biochar has been facilitated by previous research experiences in biomass. Moreover, Lieder and Rashid (2016), and Baldassarre et al. (2019) point out that the development of sustainable processes in firms, such as the application of Integrated Management Systems (ISO, 2019), or the application of Directive 2009/125/EC, for the establishment of eco-design requirements for energy-related products, or industrial symbiosis processes, in the context of circular economy, have been facilitated in their implementation by previous eco-innovations of process and organization such as the ISO 9001. Therefore, the eco-innovation process needs the generation of firms' capabilities, including the development of tasks, routines and teams in the firm. In this cumulative process, continuous learning facilitates the development of subsequent ecoinnovations. Hence, we propose:

Hypothesis 1 (Persistence): Previous experience in eco-innovation has a positive effect on firms' eco-innovation.

\section{The interrelation between innovation and eco-innovation}

Doran (2012) points out that the interrelation between capabilities arises as a consequence of the need to develop tasks and the affinity between them. In this sense, Hullova et al. (2016)

\footnotetext{
${ }^{1}$ Recent literature characterising innovation capabilities points out that in addition to intermediating between the resources and the perforation of the company, innovation capabilities must fulfil the two properties namely persistence and interrelation with other innovations (see for example, Arranz et al., 2019).
} 
study interactions among technological innovations and classify them according to two dimensions: firstly by the order of interaction, which can be simultaneous or sequential; secondly, by the degree of interaction, which can be synergistic or complementary. They find that the interaction between process and product innovation may be sequential.

First, regarding the order of interaction, Bossle et al. (2016), and Hofmann (2012) point out that innovation is a facilitator of the development of eco-innovation and that innovation is a pre-requisite for the generation of eco-innovation. In the automobile sector, for example, Sierzchula et al. (2012) find that electric car, as an eco-innovation of product, has been facilitated by the innovative capabilities of companies in the industry. Tsai and Liao (2017), analysing 2,964 Taiwanese manufacturing companies, find that the realization of previous innovations has a positive effect on eco-innovation as a consequence of innovation capability enhancing in the firms. Moreover, Hofmann (2012) points out that the simultaneous development of eco-innovation and technological and non-technological innovations facilitate the generation of eco-innovation. For example, Segarra-Oña et al. (2011) have found a correlation between the number of patents that firms developed as a result of innovation processes, and the development of eco-innovation. Chassagnon and Haned (2015) point out that innovation capability and the propensity to eco-innovate are related in the case of French firms. Hoffman et al. (2012) suggested that the adoption of advanced technology facilitates the firms' ability to implement environmental management practices and environmental collaboration. Taken all together, the literature points out towards a reciprocal or simultaneous relation between both process innovation and eco-innovation. This should not be surprising since both processes have a similarity and can share organizational processes (Robbins and O'Gorman, 2015). From a dynamic capabilities perspective, Teece (2007) pointed out that continuous learning facilitates the development of simultaneous and subsequent innovations. In this line, the eco-innovation process will be facilitated by the development of simultaneous or past innovation processes. Hence, we propose:

Hypothesis 2 a (Simultaneous Interrelation): Innovation has a positive effect on firms' ecoinnovation.

Hypothesis $2 b$ (Sequential Interrelation): Previous experience in innovation has a positive effect on firms' eco-innovation.

Lastly, we explore whether the interrelations between innovation and eco-innovation are complementary. Doran (2012, p. 354) defined complementarity across R\&D activities 'as existing if the engagement of a firm in two types of $R \& D$ activity simultaneously resulted in greater returns to the firm than engagement in either of these forms of $R \& D$ separately'. This 
means that the joint development of these two types of innovation increases the probability of a third type of innovation, as compared when these types of innovation are developed separately. In fact, there are several studies that report the potential synergistic effect of previous and future innovations in both technological and non-technological innovation (for example, Doran, 2012). This complementary effect derives from sharing competencies, resources, and routines in the process of innovation, due to the generation of economies of scale and learning (Camisón and Villar-López, 2014).

We hypothesize that the joint undertaking of eco-innovation and innovation will have a greater impact on future eco-innovation than when only eco-innovation is pursued. On the one hand, Demirel and Kesidou (2019) highlight as environmental market sensing, adaptation to environmental regulations and markets changes capabilities have a positive effect on the development of eco-innovation. On the other hand, Hofman et al. (2012) indicate that ecoinnovation is facilitated by the adoption of technological advances, as a consequence of possible cost reduction, productivity rise, or an improvement in the quality of eco-innovation development. Hence, when the development of previous eco-innovations capabilities is combined with firms' capability to develop innovations, it can be expected that this will have an even higher effect on the future development of eco-innovation than when firms only possess eco-innovation capabilities. In this line, for example, Lieder and Rashid (2016) point out that the introduction of Circular Business models is facilitated when firms combine experience in innovation developing with suppliers and customers with an adequate level of eco-innovation capabilities. Therefore, the development of both previous innovations and ecoinnovations will have a positive and complementary impact on future developments of environmental innovations in firms. Hence, we propose:

Hypothesis 3 (Complementarity): Previous experience in innovation and eco-innovation has a complementary effect on firms' eco-innovation.

\section{Methodology}

As in previous work (Arranz et al., 2019), this research considers firms as the unit of analysis and uses data from the Spanish Technological Innovation Panel (PITEC). PITEC is a database from the innovation survey that is conducted bi-annually by National Statistics Institute (INE), replicating in Spain the questionnaire used by the Community Innovation Survey (CIS). PITEC collects data about the responding companies, their innovation activities and strategies. The reference period for our study is 2008-2013, and the sample includes a total of 5,461 firms. 


\section{Dependent variable}

Following Arranz et al. (2019) and PITEC questionnaire, the dependent variable of ecoinnovation in this study is measured by four items related to four types of innovative activity that firms carried out to address environmental concerns: i) Less energy per production; ii) Lower environmental impact; iii) Improvement in health and safety; and iv) Compliance with regulatory, environmental, health, or safety requirements. Accordingly, the variable of ecoinnovation can be rated on a scale of 1 to 4 . On one hand, the variable, eco-innovation, as a sum of the four items, measures whether the company has engaged in any of the four types of eco-innovation, suggesting the diversity of eco-innovation developed by the company. On the other, as the four items are correlated (Cronbach's Alpha: 0.996), this also indicates the intensity of firms' eco-innovation ${ }^{2}$.

\section{Independent variables}

The PITEC questionnaire measures innovations with four variables (product, process, organisational and marketing). The first, product innovation, is a dummy variable that equals 1 when the company has successfully completed a product innovation. In particular, it measures whether the company has successfully concluded at least one of the following types of product innovation in the reference period: i) in goods; ii) in services.

The second variable is process innovation. The survey defines process innovation as a dummy variable that measures whether the company has successfully concluded the innovation process in the reference period. In particular, it measures whether the company has successfully concluded at least one of the following types of innovation processes in the reference period: i) in manufacturing methods; ii) in logistical systems or in the delivery and distribution methods for their inputs, goods and services; and iii) in support activities for their processes, such as systems for maintenance and IT operations, procurement and accounting.

The third is organisational innovation, which is undertaken in three ways: (i) by the internal functioning of the firm (including methods/systems of knowledge management), (ii) by the organisation of the workplace, and (iii) by the external relations the firm has not previously used. This variable is measured by a dummy variable that takes the value of 0 if no activities have taken place in that particular category and 1 otherwise.

\footnotetext{
2 To check whether the measure of eco-innovation also measures its intensity, we perform a Principal Components Analysis (PCA), obtaining a single factor for the four types of environmental innovation. This analysis explains $73.220 \%$ of the variance $(\mathrm{KMO}=.842$; sig $=.000)$. Subsequently, we perform a correlation analysis between the eco-innovation variable obtained as a sum and one obtained through the PCA The correlation value is 0.901, indicating a high correlation, and an affinity or similarity between the two variables. the result confirms that this measure can be accepted as a proxy for intensity.
} 
The last one is marketing innovation, which is also a dummy variable that takes a value of 1 when the company has successfully concluded one of four types of innovation in the reference period: (i) significant changes to the aesthetic design or packaging of a good or service using manufacturing methods, (ii) new media or techniques for product promotion, (iii) new methods for product placement or sales channels, and (iv) new methods of pricing goods or services.

\section{Control Variables}

As for control variables, the first variable is firm size. In the literature it is known that larger firms are more likely to engage in technological innovations as compared to smaller firms (Triguero et al., 2013; Ballot et al., 2015). It measures the firm size with the log of the number of employees (Firm Size).

As the second control variable, we also include a dummy variable to control for whether the company belongs to the manufacturing or services sector (Arranz et al., 2019). It is coded as 0 if it belongs to the manufacturing sector, and 1, to the service sector.

Following Arranz et al. (2019), we use a third control variable as to whether the firm belongs to a group. In this case, the PITEC questionnaire includes a dummy variable (Group), It is taken as 0 if it does not belong to a group and 1 otherwise.

The final control variable is the international scope of the firm. PITEC questionnaire establishes four different geographical markets: i) local; ii) national; iii) EU; or iv) other countries. Following Arranz et al., (2019), it includes the variable International Scope to control for whether the firm operates abroad or not. It is coded as 0 if the firm operates in local or national market, 1 if it operates in the EU market exclusively, and 2 if it operates in the US and other markets (China and India).

\section{Empirical strategy}

To test the Hypotheses 1, 2a, 2b, and 3, we use Ordinal Logit Regressions, as our dependent variable is ordinal. We use four models to analyse the effect of persistency and interrelation of eco-innovation (Table 2), and five models to analyse the complementarity effect (Table 2), in two periods of analysis: $t$ (2011-2013), and $t-1$ (2008-2010). In all models, we have used as dependent variable eco-innovation (EI) developed in the period $t$, and four control variables. More in detail:

Model 1 (Baseline Model), we have included the dependent variable with control variables (Table 2).

$$
\begin{aligned}
& \text { EI }(t)=\text { constant }+\beta_{1}(\text { Firm Size })+\beta_{2}(\text { Manufacturing } / \text { Services })+\beta_{3}(\text { Group })+\beta_{4}(\text { International } \\
& \text { Scope })+e
\end{aligned}
$$


In Model 2, we analyse the persistence of eco-innovation. In this case, we have included as the independent variable the previous eco-innovation developed in $t-1$ (Table 2).

$E I(t)=$ constant $+\beta_{1}(E I(t-1))+\beta_{2}($ Firm Size $)+\beta_{3}($ Manufacturing/Services $)+$ $\beta_{4}($ Group $)+\beta_{5}($ International Scope $)+e$

Models 3 and 4 analyse the interrelation, both sequentially and simultaneity, between ecoinnovation and innovation (Table 2). Thus, Model 3, we analyse the simultaneous interrelation, this is the impact of innovations on eco-innovation developed by companies in the $t$ period.

$E I(t)=$ constant $+\beta_{1}($ Product Innovation $(t))+\beta_{2}($ Process Innovation $(t))+$ $\beta_{3}($ Organisational Innovation $(t))+\beta_{4}($ Marketing Innovation $(t))+\beta_{5}($ Firm Size $)+$ $\beta_{6}($ Manufacturing/Services $)+\beta_{7}($ Group $)+\beta_{8}($ International Scope $)+e$

Model 4, we analyse the sequential interrelation, this is the impact of innovations of the previous period $t-1$ on eco-innovation developed by companies in the $t$ period (Table 2).

$E I(t)=$ constant $+\beta_{1}($ Product Innovation $(t-1))+\beta_{2}($ Process Innovation $(t-1))+$ $\beta_{3}($ Organisational Innovation $(t-1))+\beta_{4}($ Marketing Innovation $(t-1))+\beta_{5}($ Firm Size $)+$ $\beta_{6}($ Manufacturing/Services $)+\beta_{7}($ Group $)+\beta_{8}($ International Scope $)+e$

In Models 5 to 8 (Table 3), we test the complementarity effect of the joint eco-innovation and innovation in previous period $(t-1)$ on eco-innovation $(t)$. For this, we employ a methodology similar to that of Mohnen and Roller (2005), Sharapova and Kattuman (2010), Doran (2012), and Ballot et al. (2015), allowing the analysis of various combinations of innovation output acting as complements or substitutes ${ }^{3}$. In Model 5 , it uses the combination of eco-innovation $(i)$ and product innovation $(j)$, both in previous period $(t-1)$ as independent variables $\left(A_{x}(i, j)\right)$. This is defined as $A_{l}(1,0)=1$, when eco-innovation is only introduced and non-innovation, taking $A_{1}=0$ in the rest of the case $\left(A_{1}(0,0), A_{1}(0,1), A_{1}(1,1)\right)$. Moreover, $A_{2}(1,1)=1$, when eco-innovation is introduced together with innovation, taking $A_{2}$ the value 0 in the rest of the case $\left(A_{2}(0,0), A_{2}(0,1), A_{2}(1,0)\right)$. Following the same method, in Model 6, 7 and 8 , it defines as independent variables $B(i, k), C(i, l)$ and $D(i, m)$, combining ecoinnovation $(i)$ with process $(k)$, organisational $(l)$, and marketing innovation $(m)$ respectively.

$E I(t)=$ constant $+\beta_{1}\left(A_{1}(\right.$ Eco-innovation $\left.(t-1), 0)\right)+\beta_{2}\left(A_{2}(\right.$ Eco-innovation $(t-1)$, Productinnovation $(t-1)))+\beta_{3}($ Firm Size $)+\beta_{4}($ Manufacturing/Services $)+\beta_{5}($ Group $)+\beta_{6}($ International Scope) $+e$

\footnotetext{
${ }^{3}$ This method is used when the sample is large, since the sample must be divided into sub-samples for each of the cases.
} 
$E I(t)=$ constant $+\beta_{1}(B 1($ Eco-innovation $(t-1), 0))+\beta_{2}(B 2($ Eco-innovation $(t-1)$, Processinnovation $(t-1)))+\beta_{3}($ Firm Size $)+\beta_{4}($ Manufacturing/Services $)+$ $\beta_{5}($ Group $)+\beta_{6}($ International Scope $)+e$

$E I(t)=$ constant $+\beta_{1}\left(C_{1}(\right.$ Eco-innovation $\left.(t-1), 0)\right)+\beta_{2}\left(C_{2}(\right.$ Eco-innovation $(t-1)$, Organisational-innovation ( $t$-1) $))+\beta_{3}($ Firm Size $)+\beta_{4}($ Manufacturing/Services $)+$ $\beta_{5}($ Group $)+\beta_{6}($ International Scope $)+e$

$E I(t)=$ constant $+\beta_{1}\left(D_{1}(\right.$ Eco-innovation $\left.(t-1), 0)\right)+\beta_{2}\left(D_{2}(\right.$ Eco-innovation $(t-1)$, Marketinginnovation $(t-1)))+\beta_{3}($ Firm Size $)+\beta_{4}($ Manufacturing/Services $)+\beta_{5}($ Group $)+\beta_{6}($ International Scope) $+e$

\section{Robustness analysis}

Moreover, we have tested the robustness of all models through the Variance Inflation Factor (VIF) and Durbin-Watson, obtaining in all models acceptable values (see Tables 2 and 3). Also, we have tested the common method variance (CMV) and common method bias (CMB), following Podsakoff et al's (2003) method. This analysis reveals five distinct latent constructs that account for 62.01 percent of the variance. The first factor accounts for 19.11 percent of the variance, which is below the recommended limit of 50 percent. This result suggests CMV and CMB are not a concern in the results of our regressions.

Additionally, we have tested the robustness of this complementarity analysis with a second method (Model 9, Table 3). The independent variables are the cases when companies develop eco-innovation together with another type of innovation, namely $A_{2}, B_{2}, C_{2}$, and $D_{2}$. We have introduced these variables as categorical variables, using as reference $\mathrm{A}_{1}$.

$E I(t)=$ constant $+\beta_{1}\left(A_{2}(\right.$ Eco-innovation $(t-1)$, Product-innovation $\left.(t-1))\right)+\beta_{2}(B 2($ Ecoinnovation ( $t-1)$, Process-innovation $(t-1)))+\beta_{3}\left(C_{2}(\right.$ Eco-innovation ( $t$ - 1$)$, Organisationalinnovation $(t-1)))+\beta_{4}\left(D_{2}(\right.$ Eco-innovation $(t-1)$, Marketing-innovation $\left.(t-1))\right)+\beta_{5}($ Firm Size $)+$ $\beta_{6}($ Manufacturing/Services $)+\beta_{7}($ Group $)+\beta_{8}($ International Scope $)+e$

Therefore:

$\mathrm{H}_{0}: \beta_{i} \leq 0$, there is no complementarity.

$\mathrm{H}_{1}: \beta_{i}>0$, there is complementarity.

Thus, positive and significant values indicate that the effect of joint eco-innovation and innovation is greater on future eco-innovations than that of only previous eco-innovation.

\section{Results and Discussion}


Table 2 presents the results of our estimation. Model 1 shows the impact of the control variables on the development of various eco-innovation activities. We find there is a positive impact between firm size and environmental objectives $(\beta=3.214 \mathrm{E}-.005, \mathrm{p}<0.001)$. Although we also observe that there are small and medium companies that have assumed at least one environmental objective, our results suggest that size is a fundamental factor in the development of eco-innovation. This has been a classic result in the environmental literature, showing that large companies have a greater predisposition to the adoption of environmental objectives. Moreover, Azzone and Noci (1998b) showed that SMEs usually have limited financial resources and therefore cannot develop long processes of accumulation of competences. Nor they even allocate funds for ecological initiatives (Noci and Verganti, 1999). The result also shows that the manufacturing sector is more sensitive to the adoption of ecoinnovation objectives than the service sector $(\beta=-0.517, \mathrm{p}<0.01)$. This is in line with previous research that indicates that the manufacturing sector has a greater impact on environmental problems, such as the classic elimination of toxic waste, both gaseous and liquid, and energy saving (Tang et al., 2018; Rehfeld et al., 2007). Finally, we see that belonging to a group has a positive effect $(\beta=0.102, \mathrm{p}<0.05)$ on the adoption of certain types of innovation objectives. This is explained by previous studies that have found that firms' conglomerate or groups are in charge of determining the environmental policies. This corporate environmental strategy determines the adoption of environmental quality standards, management, and clean production processes, which is all part of the corporate social responsibility policy of the company (Arranz et al., 2019a).

Regarding Hypothesis 1 about the existence of persistence in eco-innovation, Model 2 (Table 2) shows that the realization of eco-innovation in previous periods has a positive impact $(B=0.112, p<0.001)$ on the development of subsequent innovations. This finding supports Hypothesis 1. Our results are in line with the Demirel and Kesidou (2019), which point out that sustainability-oriented capabilities have an impact on the decision to introduce eco-innovation. Also, the results are in line with the studies on the persistence over time of technological innovations (Peters, 2009; Sapprasert and Clausen, 2012; Tavassoli and Karlsson, 2015).

In the case of Hypothesis $2 a$ and 2b, the results from Models 3 and 4 (Table 2) show that the technological and non-technological innovation carried out both in the previous period $(t$ 1) and in the same period $(t)$ have a positive effect on the development of eco-innovation. More specifically, we see that either product innovation $(\beta=0.030, \mathrm{p}<0.05)$, process innovation ( $\beta$ $=0.109, \mathrm{p}<0.001)$, or organizational innovation $(\beta=0.130, \mathrm{p}<0.001)$, developed in the previous period have a positive effect on the development of eco-innovation, while there is a 
non-significant effect of prior marketing innovation. We also observe that product $(B=0.063$, $p<0.001)$, process $(B=0.136, p<0.001)$, organizational $(\beta=0.121, p<0.001)$, and marketing $(B=0.074, p<0.001)$ innovations in the same period have an impact on the development of eco-innovation. In this sense, our results are in line with the Hofmann's work (Hofmann et al., 2012), which indicates that manufacturing technology and product innovation facilitate the implementation of environmental management practices. Moreover, the results provide empirical evidence to the work of Demirel and Kesidou (2019), corroborating how the capability technologies positively affect the decision to introduce eco-innovation. Therefore, the results are also coherent with the point of view of dynamic capabilities, which indicates that the development of simultaneous and previous capabilities facilitate the development of other capabilities (for example, Teece, 2007). Therefore, as shown in the results from Models 3 and 4 , we find that innovation carried out both in the previous period $(t-l)$ and in the same period $(t)$ impact positively on the development of eco-innovation, supporting Hypotheses 2a and $2 b$.

Hypothesis 3 is related to the joint effect that previous innovation and eco-innovation has on eco-innovation. Models 5 to 8 (Table 3), which present both methodologies, partially support this hypothesis. The coefficients for the case of the joint impact of eco-innovation and product innovation $(\beta=0.229, \mathrm{p}<0.001)$, eco-innovation and process innovation $(\beta=0.217, \mathrm{p}$ $<0.001)$, and eco-innovation and organisational innovation $(\beta=0.145, \mathrm{p}<0.001)$, have greater impact on future eco-innovation as compared when eco-innovation has been conducted in isolation in the previous period. We do not find any significant effects of the joint development of eco-innovation and marketing innovation on eco-innovation. As explained above, we have conducted an alternative analysis to check for the robustness of our results (Model 9). The results display in Model 9 support the results found in Models 5 to 8. More in detail, there is a joint positive effect of eco-innovation and product innovation $(\beta=0.254, \mathrm{p}<0.001)$, ecoinnovation and process innovation $(\beta=0.210, \mathrm{p}<0.001)$, and eco-innovation and organisational innovation ( $\beta=0.041, \mathrm{p}<0.001)$, on future eco-innovation. These results complement previous studies that empirically showed that technological and non-technological innovations have a synergistic effect on future innovations (Ballot et al., 2015; Doran, 2012). Hence, within the framework of dynamic capabilities, we find that the implementation of processes and the generation of capabilities are facilitated for the learning and knowledge acquired during the development of different capabilities, which is translated into reduction of the time and economy of scale, which is required for the processes of innovation. 


\section{Conclusion}

The overall aim of this study is to investigate how innovative capabilities of the firm affect eco-innovation. First, our study extends the current literature on eco-innovation and improves our understanding of it, by providing empirical evidence to the debate regarding the relation of technological and non-technological innovations and eco-innovation. We show that ecoinnovation and innovation are interrelated both simultaneously and sequentially. Moreover, in line with recent studies on dynamic capabilities, we show that innovation capabilities and ecoinnovation are not only related, but they also have a complementary nature, which facilitates the development of future eco-innovation.

Second, we extend the literature on eco-innovation by contributing to the conceptualization of eco-innovation (see, for example, Aranduel and Kemp, 2009). In contrast to existing definitions focused on eco-innovation performance (Doran and Ryan, 2016; Kemp, 2010), we propose eco-innovation as a capability, similar to the concept of innovation capability put forward by Cohen and Levinthal (1990). In our paper, we demonstrate that eco-innovation possesses two properties of innovation capabilities, persistence over time and interrelation with other innovations. This complements other works to suggest a mediating role of eco-innovation among the generation of resources and the firm performance (Bossle et al., 2016; CarrilloHermosilla et al., 2010). It allows us to conceptualize eco-innovation to highlight the dual nature of eco-innovation as a performance and as an innovation capability. Therefore, in terms of developing a taxonomy, we consider that eco-innovation can be incorporated into the classical taxonomy of technological and non-technological innovations, with its own category.

Finally, our third contribution is in the policy-making area, where our results confirm previous studies that suggest that both technological and non-technological innovation are facilitators of the development of eco-innovation (Hofmann, 2012). Our results show that there exists a parallelism between the knowledge and skills necessary for the development of ecoinnovation and innovation, highlighting the interrelationship between both processes, which makes companies that have already developed innovations more likely to develop ecoinnovations. Thus, our contribution raises parallelism between the development of innovation and eco-innovation (Cuerva et al., 2014; Foulon et al., 2002). These findings have implications for policy makers. First, in the context of the firm, those actions targeted at developing innovation capabilities at firms should also be applicable for the development of ecoinnovations. Second, from the institutional point of view, innovation development policies might be permeable to the development of green innovations. However, we must not forget the differential aspects such as the double externality and the regulatory effect of the 
administration. Therefore, a public policy for the promotion of eco-innovations should not only be based on innovation policies but should also be considered the singularity of it.

Our research has limitations. Geographically, limiting our study to Spain, leaves open to the question of the generalizability of our results. This issue needs to be explored in countries in which innovation and eco-innovation may be more important. A second limitation stems from the data; although the questionnaire used CIS, in the Spanish version, has been widely used and analysed, containing certain characteristics such as (anonymity and confidentiality, technical questions, etc.), we must consider that this is not exempt from social desirability bias.

\section{References}

Ambec, S., Cohen, M. A., Elgie, S., \& Lanoie, P. (2013). The Porter hypothesis at 20: can environmental regulation enhance innovation and competitiveness? Review of Environmental Economics and Policy, 7(1), 2-22.

Andersen, M.M. (2010). On the Faces and Phases of Eco-innovation-on the Dynamics of the Greening of the Economy. Druid Summer Conference 2010. Imperial College, London.

Arena, C., Michelon, G., Trojanowski, G. (2018). Big Egos can be green: a study of CEO hubris and environmental innovation. British Journal of Management 29 (2), 316-336.

Arranz, N., Arroyabe, C. F., \& Fernández de Arroyabe, J. C. (2019). The effect of regional factors in the development of eco-innovations in the firm. Business Strategy and the Environment. https://doi.org/10.1002/bse.2322.

Arranz, N., Arroyabe, M. F., Li, J., \& de Arroyabe, J. F. (2019). An integrated model of organisational innovation and firm performance: Generation, persistence and complementarity. Journal of Business Research, 105, 270-282.

Arundel, A. V., \& Kemp, R. (2009). Measuring eco-innovation. (UNU-MERIT Working paper; No. 017). Maastricht: Universiteit Maastricht.

Azzone, G., \& Noci, G. (1998). Identifying effective PMSs for the deployment of "green" manufacturing strategies. International Journal of Operations \& Production Management, 18(4), 308-335.

Baldassarre, B., Schepers, M., Bocken, N., Cuppen, E., Korevaar, G., Calabretta, G. (2019). Industrial Symbiosis: towards a design process for eco-industrial clusters by integrating Circular Economy and Industrial Ecology perspectives. Journal of Cleaner Production 216, 446-460. 
Ballot, G., Fakhfakh, F., Galia, F., \& Salter, A. (2015). The fateful triangle: Complementarities in performance between product, process and organizational innovation in France and the UK. Research Policy, 44(1), 217-232.

Borghesi, S., Cainelli, G., \& Mazzanti, M. (2015). Linking emission trading to environmental innovation: evidence from the Italian manufacturing industry. Research Policy 44, 669-683.

Bossle, M. B., de Barcellos, M. D., Vieira, L. M., \& Sauvée, L. (2016). The drivers for adoption of eco-innovation. Journal of Cleaner Production, 113, 861-872.

Cai, W.G., \& Zhou, X.L. (2014). On the drivers of eco-innovation: empirical evidence from China. Journal of Cleaner Production, 79, 239-248.

Cainelli, G., Mazzanti, M. \& Montresor, S. (2012). Environmental innovations, local networks and internationalization, Industry and Innovation, 19(8), 697-734.

Camisón, C., \& Villar-López, A. (2014). Organizational innovation as an enabler of technological innovation capabilities and firm performance. Journal of Business Research, 67(1), 2891-2902.

Carraro, C. (2000). Environmental Technological Innovation and Diffusion: Model Analysis. In: Hemmelskamp, J., Leone, F. and Rennings, K. (eds.), Innovation-oriented Environmental Regulation: Theoretical Approaches and Empirical Analysis, Physica, Heidelberg, New York, 269-297.

Carrillo-Hermosilla, J., del Río, P., \& Könnölä, T. (2010). Diversity of eco-innovations: Reflections from selected case studies. Journal of Cleaner Production, 18(10), 1073-1083.

Chassagnon, V., \& Haned, N. (2015). The relevance of innovation leadership for environmental benefits: A firm-level empirical analysis on French firms. Technological Forecasting and social change, 91(1), 194-207.Cohen, W. M., \& Levinthal, D. A. (1990). Absorptive capacity: A new perspective on learning and innovation. Administrative Science Quarterly, 35(1), 128-152.

Costantini, V., Crespi, F., \& Palma, A. (2017). Characterizing the policy mix and its impact on eco-innovation: A patent analysis of energy-efficient technologies. Research Policy, 46(4), 799-819.

Cuerva, M.C., Triguero-Cano, Á., \& Córcoles, D. (2014). Drivers of green and non-green innovation: empirical evidence in low-tech SMEs. Journal of Clean Production, 68, 104113.

Dangelico, R. M., Pujari, D., \& Pontrandolfo, P. (2017). Green product innovation in manufacturing firms: A sustainability-oriented dynamic capability perspective. Business Strategy and the Environment, 26(4), 490-506. 
Dangelico, R.M. (2016). Green product innovation: where we are and where we are going. Business Strategy and the Environment 25(8), 560-576.

De Marchi, V. (2012). Environmental innovation and R\&D cooperation: Empirical evidence from Spanish manufacturing firms. Research Policy, 41(3), 614-623.

Del Río, P., Peñasco, C., \& Romero-Jordán, D. (2015). Distinctive features of environmental innovators: an econometric analysis. Business Strategy and the Environment, 24(6), 361385.

Demirel, P., \& Kesidou, E. (2019). Sustainability-oriented capabilities for eco-innovation: Meeting the regulatory, technology, and market demands. Business Strategy and the Environment. https://doi.org/10.1002/bse.2286

Doran, J. (2012). Are differing forms of innovation complements or substitutes? European Journal of Innovation Management, 15(3), 351-371.

Doran, J., \& Ryan, G. (2016). The importance of the diverse drivers and types of environmental innovation for firm performance. Business Strategy and the Environment, 25(2), 102-119.

Eco-Innovation Observatory (2018). Eco-innovation Index. Eco-Innovation Observatory. European Commission. http://www.eco-innovation.eu/index.php/ecoinnovation-index.

Eisenhardt, K. M., \& Martin, J. A. (2000). Dynamic capabilities: what are they? Strategic Management Journal, 21(10-11), 1105-1121.

Foulon, J., Lanoie, P., \& Laplante, B. (2002). Incentive for pollution control: regulation or information? Journal of Environmental Economic Management, 44, 169-187.

Frondel, M., Horbach, J., \& Rennings, K. (2007). End-of-pipe or cleaner production? An empirical comparison of environmental innovation decisions across OECD countries. Business Strategy and the Environment, 16(8), 571-584.

Hofmann, K. H., Theyel, G., \& Wood, C. H. (2012). Identifying firm capabilities as drivers of environmental management and sustainability practices-evidence from small and mediumsized manufacturers. Business Strategy and the Environment, 21(8), 530-545

Horbach, J. (2008). Determinants of environmental innovation - new evidence from German panel data sources. Research Policy 37, 163-173.

Horbach, J., Rammer, C., \& Rennings, K. (2012). Determinants of eco-innovations by type of environmental impact. The role of regulatory push/pull, technology push and market pull. Ecological Economics. 78, 112-122.

Hullova, D., Trott, P., \& Simms, C. D. (2016). Uncovering the reciprocal complementarity between product and process innovation. Research Policy, 45(5), 929-940. 
ISO (2019). Integrated Management Systems. International Organization for Standardization. https://www.iso.org/news/2013/02/Ref1709.html.

Kemp, D. (2010). Community relations in the global mining industry: exploring the internal dimensions of externally orientated work. Corporate Social Responsibility and Environmental Management, 17(1), 1-14.

Lieder, M. \& Rashid, A. (2016). Towards circular economy implementation: a comprehensive review in context of manufacturing industry. Journal of Cleaner Production, 115, 36-51.

Mazzanti, M., \& Zoboli, R. (2006). Economic instruments and induced innovation: the European policies on end-of-life vehicles. Ecological Economics, 58, 318-337.

Moore, M. L., von der Porten, S., Plummer, R., Brandes, O., \& Baird, J. (2014). Water policy reform and innovation: A systematic review. Environmental Science \& Policy, 38, 263-271.

Nelson, R. R., \& Winter, S. G. (2002). Evolutionary theorizing in economics. Journal of Economic Perspectives, 16(2), 23-46.

Noci, G., \& Verganti, R. (1999). Managing 'green'product innovation in small firms. $R \& D$ Management, 29(1), 3-15.

Novellie, P., Biggs, H., \& Roux, D. (2016). National laws and policies can enable or confound adaptive governance: Examples from South African national parks. Environmental Science \& Policy, 66, 40-46.

OCDE (2009). Sustainable manufacturing and eco-innovation. Framework, Practices and Measurement. Synthesis Report. https://www.oecd.org/innovation/inno/43423689.pdf

Peters, B. (2009). Persistence of innovation: stylised facts and panel data evidence. The Journal of Technology Transfer, 34(2), 226-243.

PITEC (2013). Panel de Innovacion Tecnologica. Fundacion Española para la Ciencia y Tecnologia. https://icono.fecyt.es/PITEC/Paginas/descarga_bbdd.aspx

Podsakoff, P.M., MacKenzie, S.B. Lee, J.Y. and Podsakoff, N.P. (2003). Common method biases in behavioral research: A critical review of the literature and recommended remedies. Journal of Applied Psychology, 88, 879-903.

Porter, M. E., \& Van der Linde, C. (1995). Toward a new conception of the environmentcompetitiveness relationship. Journal of Economic Perspectives, 9(4), 97-118.

Rehfeld, K.M., Rennings, K., \& Ziegler, A. (2007). Integrated product policy and environmental product innovations: an empirical analysis. Ecological Economics, 61, 91100.

Robbins, P., \& O'Gorman, C. (2015). Innovating the innovation process: an organisational experiment in global pharma pursuing radical innovation. $R \& D$ Management, 45(1), 76-93. 
Sapprasert, K., \& Clausen, T. H. (2012). Organizational innovation and its effects. Industrial and Corporate Change, 21(5), 1283-1305.

Segarra-Oña, M. D. V., Peiró-Signes, A., Albors-Garrigós, J., \& Miret-Pastor, P. (2011). Impact of innovative practices in environmentally focused firms: Moderating factors. International Journal of Environmental Research, 5(2), 425-434.

Sierzchula, W., Bakker, S., Maat, K., \& Van Wee, B. (2012). The competitive environment of electric vehicles: An analysis of prototype and production models. Environmental Innovation and Societal Transitions, 2, 49-65.

Spokas, K.A., Cantrell, K.B., Novak, J.M., Archer, D.W., Ippolito, J.A., Collins, H.P., Boateng, A.A., Lima, I.M., Lamb, M.C., McAloon, A.J., Lentz, R.D. \& Nichols, K.A. (2012). Biochar: a synthesis of its agronomic impact beyond carbon sequestration. Journal of Environmental Quality, 41 (4), 973-989.

Tang, M., Walsh, G., Lerner, D., Fitza, M. A., \& Li, Q. (2018). Green Innovation, Managerial Concern and Firm Performance: An Empirical Study. Business Strategy and the Environment, 27(1), 39-51.

Tarí, J. J., E. Claver-Cortes, J. Pereira-Moline, \& J. F. MolinaAzorín (2010). Levels of quality and environmental management in the hotel industry: Their joint influence on firm performance. International Journal of Hospitality Management 29 (3): 500-10.

Tavassoli, S., \& Karlsson, C. (2015). Persistence of various types of innovation analyzed and explained. Research Policy, 44(10), 1887-1901.

Tatoglu, E., Frynas, J. G., Bayraktar, E., Demirbag, M., Sahadev, S., Doh, J., \& Koh, S. L. (2019). Why do Emerging Market Firms Engage in Voluntary Environmental Management Practices? A Strategic Choice Perspective. British Journal of Management. https://doi.org/10.1111/1467-8551.12351.

Teece, D. J. (2007). Explicating dynamic capabilities: the nature and microfoundations of (sustainable) enterprise performance. Strategic Management Journal, 28(13), 1319-1350.

Teece, D. J., Pisano, G., \& Shuen, A. (1997). Dynamic capabilities and strategic management. Strategic Management Journal, 18(7), 509-533.

Teeter, P., \& Sandberg, J. (2017). Constraining or enabling green capability development? How policy uncertainty affects organizational responses to flexible environmental regulations. British Journal of Management, 28(4), 649-665.

Triguero, A., Mondéjar, M.L., \& Davia, M.A. (2013). Drivers of different types of ecoinnovation in European SMEs. Ecological Economics. 92, 25-33. 
Tsai, K. H., \& Liao, Y. C. (2017). Innovation capacity and the implementation of ecoinnovation: Toward a contingency perspective. Business Strategy and the Environment, 26(7), 1000-1013.

Zahra, S. A., Sapienza, H. J., \& Davidsson, P. (2006). Entrepreneurship and dynamic capabilities: A review, model and research agenda. Journal of Management Studies, 43(4), 917-955.

Zubeltzu-Jaka, E., Erauskin-Tolosa, A., \& Heras-Saizarbitoria, I. (2018). Shedding light on the determinants of eco-innovation: A meta-analytic study. Business Strategy and the Environment, 27(7), 1093-1103. 
Table 1. Conceptualisation of eco-innovation

Eco-innovation - Carrillo-Hermosilla et al. (2010) consider eco-innovation as an innovation that is able to produce environmental and sustainable products and services.

- Rennings (2000) and Kemp et al. (2006) affirm that environmental innovation is the development of a product, process, service or organizational innovation and that the final objectives are the reduction of pollution and the sustainability of the economy.

- Kemp et al. (2006) and OECD (2009): Eco-innovation aims to develop new processes, products and techniques to avoid environmental damage, including new knowledge and organizational innovation.

- In general: eco-innovation refers to innovation in new products, services or new business practices, necessary to create new business opportunities and benefits to the environment (Beise and Rennings, 2005; Jansson, 2011; Doran and Ryan, 2016)

Key elements of 1 . Eco-innovation generates environmental improvements.

eco-innovation 2. Eco-innovation obtains an additional value.

(Arranz et al.,

3. Eco-innovation develops new business niches or generates better competitive behaviour.

Mechanism of 1. Target refers to the focus of eco-innovation: Products, Processes, Marketing methods, eco-innovation and Organisations.

(OECD, 2009)

2. The mechanism is the method by which the change in the eco-innovation target takes place or is introduced. Four basic mechanisms are identified: Modification, Redesign, Alternatives, and Creation.

3. Impact refers to the eco-innovations effect on the environment, across its lifecycle. Eco-innovation and Innovation (Arranz et al., 2019)

\begin{tabular}{ll}
\hline Similarities & Eco-innovation and Innovation (Arranz et al., 2019) \\
\hline Differences & $\begin{array}{l}\text { Kemp et al. (2006) consider eco-innovation as an innovation, which is capable of } \\
\text { producing environmental and sustainable products and services. }\end{array}$ \\
(Arranz et al., 2019) & $\begin{array}{l}\text { 1. Eco-innovation generates a 'win-win' outcome (compatibility of economic } \\
\text { development and a sustainable economy). } \\
\text { 2. Eco-innovations are originated from environmental problems that need urgent } \\
\text { solutions. } \\
\text { 3. Eco-innovation has the characteristic of double externality. } \\
\text { 4. Eco-innovation has the characteristic of regulatory push/pull effect. }\end{array}$ \\
\end{tabular}


Table 2. Regression Analysis: persistence and interrelation properties in eco-innovation

\begin{tabular}{|c|c|c|c|c|c|c|c|c|}
\hline & \multicolumn{8}{|c|}{ Eco-innovation } \\
\hline & \multicolumn{2}{|l|}{ Model 1} & \multicolumn{2}{|c|}{ Model 2} & \multicolumn{2}{|c|}{ Model 3} & \multicolumn{2}{|c|}{ Model 4} \\
\hline & Estimated & VIF & Estimated & VIF & Estimated & VIF & Estimated & VIF \\
\hline Eco-innovation (t-1) & & & $.112 * * *$ & 1.031 & & & & \\
\hline Product Innovation (t) & & & & & $.063 * * *$ & 1.111 & & \\
\hline Process Innovation $(\mathrm{t})$ & & & & & $.136 * * *$ & 1.119 & & \\
\hline Organizational Innovation (t) & & & & & $.121 * * *$ & 1.291 & & \\
\hline Marketing Innovation (t) & & & & & $.074 * * *$ & 1.275 & & \\
\hline Product Innovation (t-1) & & & & & & & $.030^{*}$ & 1.176 \\
\hline Process Innovation $(\mathrm{t}-1)$ & & & & & & & $.109^{* * *}$ & 1.139 \\
\hline Organizational Innovation (t-1) & & & & & & & $.130 * * *$ & 1.367 \\
\hline Marketing Innovation (t-1) & & & & & & & .003 & 1.317 \\
\hline Firm Size & $3.214 \mathrm{E}-005^{* * *}$ & 1.009 & $.031 *$ & 1.020 & $.041 * *$ & 1.017 & $.132 * *$ & 1.319 \\
\hline Manufacturing/Services & $-.517 * *$ & 1.032 & $-.320 * * *$ & 1.609 & $-.342 * * *$ & 1.626 & $-.426 * * *$ & 1.220 \\
\hline Group & $.102 *$ & 1.538 & $.038^{*}$ & 1.742 & $.042 *$ & 1.745 & $.090^{*}$ & 1.817 \\
\hline International Scope & .050 & 1.421 & .047 & 1.835 & .054 & 1827 & .020 & 1.562 \\
\hline -2 Log Likelihood & 20239.092 & & 27450.193 & & 34920.163 & & 31042.293 & \\
\hline Chi-Square & 280.156 & & 291.148 & & 350.701 & & 292.852 & \\
\hline Sig. & .000 & & .000 & & .000 & & .000 & \\
\hline Cox and Snell & .173 & & .189 & & .210 & & .209 & \\
\hline Nagelkerke & .165 & & .166 & & .192 & & .205 & \\
\hline McFadden & .122 & & .118 & & .145 & & .178 & \\
\hline
\end{tabular}

Model 2: Durbin-Watson (1.942); Model 3: Durbin-Watson (1.942); Model 4: Durbin-Watson (1.968); Model 5: Durbin-Watson (1.915) $* \mathrm{p}<0.05, * * \mathrm{p}<0.01, * * * \mathrm{p}<0.001$ 
Table 3. Regression Analysis: complementary property in eco-innovation

\begin{tabular}{|c|c|c|c|c|c|c|}
\hline & \multicolumn{6}{|c|}{ Eco-innovation } \\
\hline & \multirow{2}{*}{$\begin{array}{c}\text { Model } 5 \\
\text { Estimated } \\
\end{array}$} & \multirow{2}{*}{$\begin{array}{c}\text { Model } 6 \\
\text { Estimated }\end{array}$} & \multirow{2}{*}{$\begin{array}{c}\text { Model } 7 \\
\text { Estimated } \\
\end{array}$} & \multirow{2}{*}{$\begin{array}{c}\text { Model } 8 \\
\text { Estimated } \\
\end{array}$} & \multicolumn{2}{|c|}{ Model 9} \\
\hline & & & & & Estimated & VIF \\
\hline $\mathrm{A}_{1}($ Eco-innovation $(\mathrm{t}-1), 0)$ & $.097 * * *$ & & & & & \\
\hline $\mathrm{A}_{2}($ Eco-innovation $(\mathrm{t}-1)$, Product Innovation (t-1)) & $.229 * * *$ & & & & & \\
\hline $\mathrm{B}_{1}($ Eco-innovation $(\mathrm{t}-1), 0)$ & & $.091 * * *$ & & & & \\
\hline $\mathrm{B}_{2}($ Eco-innovation $(\mathrm{t}-1)$, Process Innovation $(\mathrm{t}-1))$ & & $.217 * * *$ & & & & \\
\hline $\mathrm{C}_{1}($ Eco-innovation $(\mathrm{t}-1), 0)$ & & & $.102 * * *$ & & & \\
\hline $\mathrm{C}_{2}$ (Eco-innovation ( $\left.\mathrm{t}-1\right)$, Organisational Innovation(t-1) & & & $.145^{* * *}$ & & & \\
\hline $\mathrm{D}_{1}($ Eco-innovation $(\mathrm{t}-1), 0)$ & & & & $.123 * * *$ & & \\
\hline $\mathrm{D}_{2}($ Eco-innovation $(\mathrm{t}-1)$, Marketing Innovation (t-1)) & & & & .053 & & \\
\hline $\mathrm{A}_{1}($ Eco-innovation $(\mathrm{t}-1), 0)$ & & & & & .0 & 1.267 \\
\hline $\mathrm{A}_{2}($ Eco-innovation (t-1), Product Innovation (t-1)) & & & & & $.254 * * *$ & 2.303 \\
\hline B2(Eco-innovation (t-1), Process Innovation (t-1)) & & & & & $.210^{* * *}$ & 2.210 \\
\hline C2(Eco-innovation (t-1), Organisational Innovation (t-1)) & & & & & $.041 * *$ & 1.425 \\
\hline D2(Eco-innovation (t-1), Marketing Innovation (t-1)) & & & & & .006 & 1.347 \\
\hline Firm Size & $0.47 * * *$ & $1.01 * * *$ & $3.214 \mathrm{E}-005^{* * *}$ & $3.214 \mathrm{E}-005^{* * *}$ & $.036^{* *}$ & 1.013 \\
\hline Manufacturing/Services & $-.309 * * *$ & $-.418 * *$ & $-.509 * * *$ & $-.492 * * *$ & $-.539 * * *$ & 1.619 \\
\hline Group & $.145^{* *}$ & $.127^{*}$ & $.125 * *$ & $.092 *$ & $.084 *$ & 1.804 \\
\hline International Scope & .031 & .027 & .092 & .004 & .038 & 1.724 \\
\hline -2 Log Likelihood & 20109.340 & 28316.125 & 29937.178 & 27114.120 & 30979.550 & \\
\hline Chi-Square & 210.327 & 277.068 & 278.099 & 264.823 & 367.048 & \\
\hline Sig. & .000 & .000 & .000 & .000 & .000 & \\
\hline Cox and Snell & .166 & .181 & .201 & .199 & .234 & \\
\hline Nagelkerke & .153 & .169 & .189 & .181 & 198 & \\
\hline McFadden & .110 & .127 & .155 & .143 & .175 & \\
\hline
\end{tabular}

